\title{
The Musharraf Paradox: The Failure of an Economic Success Story
}

\author{
Robert Looney* \\ Postgraduate School, Monterey, California, USA
}

\begin{abstract}
Despite some of the more rapid rates of economic growth seen in Pakistan in years, the government of Pakistan's Pervez Musharraf was soundly rejected by voters in early 2008. To the surprise of many observers, it was the economy, rather than increased violence, the war on terrorism, or the authoritarian nature of the regime that was the prime concern of electorate. It appears that much of the macro-economic successes did not trickle down very far - increased income inequalities and regional disparities, rising inflation only added to the electorate's frustrations. After examining the country's pattern of growth and the results of Musharraf's economic programs, a more fundamental criticism can be made - the economic development model adopted over the last eight years is unlikely to have laid a solid foundation for further growth.
\end{abstract}

\section{INTRODUCTION}

The February 19, 2008 election defeat of Pakistan's President Pervez Musharraf was not a major surprise. When asked to list the most important issue for voters, most observers of the Pakistan scene would list factors such as: (a) the deteriorating security situation evidenced by the increase in terrorist attacks over the past year, (b) the suppression of civil rights through President Pervez Musharraf's heavyhanded sacking of the country's top judges, (c) the unpopular partnership with the United States in the war on terrorism, (d) the rise and spread of extremism, and (e) the suspicious assassination of former Prime Minister Benazir Bhutto. Surprisingly, for most voters a more basic set of issues prevailed:

People were angry over the fact atta [flour] was not available, that food prices were high, and due to this they felt insecure. It's a familiar lament in Pakistan these days. We are worried about terrorism and those other things, but first we are worried about basic needs. People want a person who can fix this problem [1].

Perhaps because Pakistan is viewed as having one of the best economic growth records in the region over the last eight years, economic factors were largely overlooked as contributing elements to the General's electoral defeat. This perception was reinforced by the poor state of the economy inherited by Musharraf. During the 1990s Pakistan's economy underperformed with per capita incomes averaging around $1 \%$ per annum. Several factors contributed to the country's economic malaise. First the civilian ruling elites failed to make efficient use of public financial resources to boost economic growth, contain poverty, and develop human resources. Second these governments (B. Bhutto and N. Sharif) failed to check unbridled corruption and cronyism. The result was an increasing political use of public resources, the bending of rules and regulations to benefit a

*Address correspondence to this author at the Postgraduate School, Monterey, California, USA, Tel: 831-656-3484; Fax: 831-656-2949;

E-mail: relooney@nps.edu selected few and the erosion of any institutional accountability [2].

Four key economic breakdowns evolved out of this environment: (1) high fiscal deficits; (2) an unsustainable public debt (domestic and foreign) and (3) a sharp deterioration in the distribution of income; and (4) a disturbing rise in the level of unemployment [3] and poverty [4]. The reforms introduced by the Musharraf administration after seizing power in October 1999 were clearly designed to address many these problems, including the country's massive poverty, stagnant economic growth, deteriorating institutional framework and weak governance structures.

A day before being sworn in for a new five-year presidential term that he arranged under a much criticized referendum, General Musharraf noted that the next five years were very important for Pakistan and hoped that the new government would take advantage of the "sound macroeconomic policies" framed by his regime. "If Pakistan follows the course and implements the strategy that has been crafted after much deliberations and with great care, dividends would soon be there for us to reap," he stated, further adding that his administration had [5] "pulled a rudderless ship out of the storm sail." In this regard, he noted that he and his colleagues took pride in the fact that after more than two decades of stagnation, they had "brought the country to a take-off stage" and it was now time for the elected government to "build on the bricks laid by his team." Finally, he explained that he had taken certain difficult decisions in the larger and long-term interest of the country, and particularly, in the interest of its economic and political stability.

Musharraf's regime embraced globalization making structural reforms, opening the country to investment and trade. The results surprised even his most ardent supporters -- the size of the economy increased by almost 50 percent, with income per-capita up by nearly 25 percent. Cities and towns seem to be booming. The country managed to recover impressively from the devastating earthquake in 2005 [6]. In short, the economic paradox of Muisharraf's fall from grace 
is that the country's economic performance was commendable by most standard measures:

- In the last several years the economy has grown at rates between $7.0 \%$ and $7.5 \%$.

- The share of industry in GDP rose from $22.6 \%$ in 2000 to $26.7 \%$ in 2006 .

- The annual percentage growth in industrial value added as doubled.

- The share of gross fixed capital formation in GDP has increased by three percentage points.

- The services sector has posted an impressive performance, with annual growth of the value added in services nearly doubling over the past seven years.

- There are now 82 mobile phone subscribers per 1,000 people up from two in 2000.

In a similar vein, Robert Hathaway has noted [7] that several recent and widely acclaimed books have "perpetuates a stereotype of a violence-ridden, military dominated, extremist Pakistan that does not convey the richness or vitality of the country...neither book for instance, explains the economic confidence that is this moment, driving the construction of three new five-star hotels in Islamabad [8]."

Yet, despite the impressive economic recovery under Musharraf, his party want down to a stunning defeat with economic issues a major factor in contributing to its demise. What went wrong? How could such a surge in economic activity over the last eight years following a decade of stagnant growth culminate in such a sound rejection? What was associated with the Musharraf recovery that alienated broad segments of the Pakistani citizenry?

As the following sections demonstrate, objective evaluations of the country's economic performance during the Musharraf years are difficult as a mixed picture emerges. Clearly objectivity over the Musharraf programs has been colored by divergent perceptions - the product of a sharply polarized political environment [9]. Most observers of the country's attempts at economic progress during this period fall, into two broad schools of interpretation: (1) the take-off school, and (2) the failed take-off school. Another school of thought, the structuralist or demolition school contends that no real acceleration in growth occurred under Musharraf simply put, growth under Musharraf was the result of a number of fortuitous events - post 9/11 aid flows, good weather, high remittances from workers in the booming Gulf countries and the like. There is an element of truth to this interpretation. However, the high rates of growth achieved in Pakistan over the last five years cast considerable doubt on this interpretation - it simply doesn't go far enough in explaining the economy's recent dynamics.

At issue then is whether, as the take-off school contends, the Musharraf programs despite their wide-spread unpopularity have positioned the economy on a path of high sustained growth. The failed-take off school questions the sustainability of the current expansion. Its main proposition [10] is that developing countries like Pakistan evolve through various states with improved governance and increased economic reforms paving the transition from one phase to another - without these institutional improvements growth in one stage cannot carry over to the next phase of development - a failed-take off.

This school suggests that the Musharraf years did not address many of the country's underlying governance and economic constraints on growth and by not doing so have only positioned the country for yet another replication of past patterns of boom and bust. As developments in mid2007 and into 2008 suggest, there is abundant reason to assume that the failed-take off school interpretation held by large masses of the population best captures the consequences of Musharraf's economic programs.

\section{KEY FACTORS LIMITING SUSTAINED GROWTH IN PRE-MUSHARRAF PAKISTAN}

William Easterly has provided a good overview of the economic problems facing Musharraf upon seizing power in 1989. In fact, Easterly has termed Pakistan's experience as an illustration a "growth without development [11]". Easterly contends that over the years country's poor social indicators, have lowered the productive potential economy and its ability to service its high debt. While certain degree of development and growth was attainable with skilled managerial elite and unskilled workers, over time, the economy encountered diminishing returns, as human capital did not grow at the same rate as the capital stock. Weak governance structures and limited economic reforms aids in explaining slowdown in growth in the years leading up to the Musharraf take-over.

More bluntly Shahid Husain [12] has attributed the country's inability to sustain high growth to the following factors:

1. An increase in the role of the state has coincided with a decline in governance.

2. Non-competitive regimes politically and economically have resulted in rampant corruption and stagnation - the subversion of competitiveness was the central feature of Pakistani governments.

3. There has been a continuous redistribution of wealth in favor of privileged. groups

4. A hard crust of economic monopoly has stifled new growth and creativity.

5. An erosion in the provision of public services has resulted in a decline of the public's trust in government which is seen a predatory. This, in turn, is linked to nonpayment of taxes, the corruption in tax administration, and the massive increase in borrowing.

6. The quality of the civil bureaucracy is falling rapidly. A majority of civil servants are not even paid a living wage and this is tantamount to an incentive to corruption.

7. The irrelevance of the state in the lives of the people is exemplified by the total breakdown of law and order.

8. The inability and unwillingness of the state to discharge its social services has meant a vacuum in social services. Pakistan's literacy rate has remained almost unchanged since independence. The dependence on madrassahs (religious schools) is hence understandable.

From this, Hasain correctly concludes that little economic progress, not alone a take-off is possible until the 
government is able to re-establish its presence in the political, social, and economic lives of the people.

These factors can all be grouped into a system characterized by the dominance of diversion over production. As Kazmi [13] notes:

This dominance results in the unfettered exploitation of the real producers of goods and services and unchecked accumulation of wealth and resources by the 'diverters' in the society. The chief characteristics of the diversion based societies can be identified as the unjust property rights, the outdated judicial and legal framework, powerlessness of the working classes, the ascendancy of feudalistic norms and a highly inefficient and corrupt government machinery.

Finally, there is empirical support that the diversionary economy suffers from low productivity capable of stifling long periods of high growth. Hall and Jones (1996) have developed an index of anti-diversionary policy consisting of five main components. Two of the categories relate to the government's role in protecting against private diversion: (1) law and order, and (2) bureaucratic quality. Three categories relate to the government's possible role as a diverter: (1) corruption, (2) risk of expropriation, and (3) government repudiation of contracts. They find that an equal weighted index is highly correlated with output per worker. Bureaucratic quality, law and order along with corruption remain a problem in Pakistan with the other two elements presenting a lesser challenge.

\section{THE MUSHARRAF REFORM EFFORTS}

For its part, the Musharraf administration appears to have recognized many of the growth impeding forces plaguing Pakistan over the years. Soon after taking power in October of 1999, the new government initiated a comprehensive macroeconomic stabilization program as well as a series of reforms designed to address many of the economic and institutional constraints limiting the country's ability to sustain growth.

\section{The Musharraf Reforms}

Specifically the strategy envisaged four key goals:

1. Macroeconomic stability and the restoration of a working relationship with international financial institutions (mainly the IMF, World Bank and the Asian Development Bank).

2. Structural reforms to remove distortions in the economy.

3. Improving governance, especially economic, and reviving key national institutions.

4. Poverty alleviation measures.

The main thrust of the Musharraf reforms were to improve not only the country's economy, but, in addition its governance and key institutions. The agenda for improving governance is based on the devolution of power, improved public financial management/accountability, fighting corruption and civil service, judicial, and police reforms.

The implicit priorities underlying this approach are straightforward: good governance, economic revival based on strong fundamentals and freedom from debt and social harmony are interdependent goals. The overriding philosophy of the Musharraf government is that distortions in the economy are great inhibitors in achieving these objectives and thus have to be removed. The government's economic team and the IMF and World Bank staff shared Musharraf's diagnosis of the problems confronting the economy and the prescriptions required to fix them.

In sum, the Musharraf reforms need to be seen as a process unfolding over time. The first phase was to restore growth through macroeconomic stability and market reforms focused on increased total factor productivity and globalization. The second stage was to develop a governance structure capable of sustaining growth over a longer period.

\section{The IMF Programs}

IMF involvement in these reforms was not immediate. The relationship between Pakistan and the IMF in the early days of the Musharraf regime was strained. The IMF and its major contributors did not take the dismissal of a democratically elected government and the takeover by a military leader lightly. In addition, the new government had to inform the Fund about Pakistan's misreporting of the official deficit data for FY1998-99. As a result of these factors and the failed programs of the 1990s, the government lacked credibility with the Fund. The failed programs in the 1990s only compounded the Fund's suspicion that the country was incapable of delivering on its commitments.

Finally, around a year after the military coup that brought President Musharraf to power in Pakistan, the Executive Board of the IMF approved a Stand-by-Credit of U.S. $\$ 596$ million. The program was to run until the end of September 2001, supporting the Government's economic program for 2000-01. The program aimed to move Pakistan on to a high and sustainable growth path by strengthening its balance of payments position, rebuilding official reserves, and reducing public sector indebtedness. To support these objectives, the Government has strengthened macroeconomic policies and as noted above, developed a wide-ranging structural reform agenda that emphasizes revenue mobilization, improving investor confidence, poverty alleviation, and good governance. The IMF credit was subject to the following requirements:

1. A reduction in the overall budget deficit in 2000-01 to $5.2 \%$ of GDP from $6.4 \%$ in $1999-2000$, with further consolidation over the medium term. This was to be achieved through increased tax collections, with a widening of the tax base, improved tax administration and strict expenditure controls. Since there is sufficient uncertainty surrounding the short-term impact of revenue measures on the budgetary position, the authorities should stand ready to take additional measures if revenues fall short of expectations.

2. Increased spending by close to one-third on poverty reduction and decrease in less productive spending.

3. An increase in gross official reserves from U.S. \$1.114 billion (at the start of the program) to U.S. $\$ 1.74$ billion at the end of June 2001, equivalent to 7.3 weeks of imports of goods and services, to be achieved through a flexible exchange rate policy, monetary tightening, fiscal adjustment, substantial exceptional financing, increased 
exports and sharply reduced private sector capital outflows brought about by a restoration of investor confidence.

4. Adequate expenditure control mechanisms would be put in place to ensure that the defense budget remains within the agreed limit and does not exceed the allocations as had happened in 1999-2000, when it increased by R \$7 billion beyond the approved allocation.

The IMF terms were quite strict, but the country, after the many failures of the 1990s was in a very poor bargaining position. The country was on the verge of a serious financial collapse and the new government had assumed power with a commitment to avert this crisis.

The SBA was fully implemented without any problems. The country's improved standing with the IMF enabled the government to qualify for another IMF program, a three year Poverty Reduction and Growth Facility (PRGF) approved in 2001 that is well underway.

As noted above, the Administration's economic strategy from the beginning was been relatively straight-forward: first stabilize the economy and then restructure. It was assumed that growth would return with stabilization. There are several implicit assumptions here: (1) Pakistan's tricky economic situation could not be addressed unless the donor community helped reduce the burden of debt the country carried; (2) to get the donors to help Pakistan, the country had to first successfully complete an IMF stabilization program; and (3) once the burden of debt had become lighter, Pakistan would have the resources needed to jump-start the economy.

The strategy was predicated on creating an environment that will attract high inflows of private foreign investment. Without these foreign funds to supplement low domestic rates of savings, the country will not be able to return to respectable rates of economic growth. The idea was that once growth was reestablished there would likely be adequate funds to combat terrorism on two fronts: (1) poverty reduction and improved governance; and (2) increased allocations to security and force modernization. With improved growth and modernization of institutions, the attractiveness of terrorism would diminish. In turn this would create an environment more conducive for further inflows of capital. In this sense, the IMF programs and the war on terrorism would complement each other.

\section{PROGRESS UNDER MUSHARRAF}

The Take-Off School noted above contends that the economic expansion initiated under Musharraf did not occur all of a sudden, but instead was the outcome of deliberate and carefully designed program of economic reforms undertaken (and some ongoing) during the first five years of the Musharraf era. The program consisted of four key elements [14]:

1. Restoration of macroeconomic stability and Pakistan's relationship with the international financial institutions.

2. Structural reforms to remove distortions.

3. Improving economic governance and reviving key institutions.

4. Poverty alleviation through targeted interventions and social safety nets.
The program was predicated on the assumption in Pakistan's case of a strong interconnection between economic growth, poverty reduction, structural reforms and improved governance. Successfully undertaken these four key components are capable of generating a virtuous circle of accelerated growth, expanded reforms and poverty reduction. Or, as Ishrat Hussain observed:

Macroeconomic stability and the consequent rapid economic growth help reduce poverty in with investment in social sectors, targeted interventions and social safety nets. Structural reforms are needed to strengthen the underpinning of macroeconomic policies and to remove microeconomic distortions affecting key sectors of the economy thus paving the way for accelerating economic growth. Improved governance affects the quality of growth by allocating realization of higher returns on investment and is also conducive to poverty reduction through better delivery of social services to the poor. Poverty reduction as we know by now can be achieved with rapid economic growth, structural reforms and improved governance.

With this strategy in place, the take-off school led by Prime Minister Shaukat Aziz, Ishrat Hussain, Governor of the State Bank of Pakistan and the supporters [15] of the Musharraf Reforms and the IMF took heart in a long list of initial successes:

- The fiscal deficit, which averaged 7.0 per cent of GDP for two decades, is expected to declined to 3.8 per cent in the fiscal year (2002-03).

- Domestic debt, which was growing at an average rate of 24.0 per cent and 16 per cent per annum during the $1980 \mathrm{~s}$ and 1990s, respectively declined slightly in 2002-03.

- Domestic debt as percentage of GDP has declined from 52 per cent in 1999-2000 to 39.3 per cent in 2002-03.

- Tax collection has increased by Rs152 billion during the last four years as opposed to Rs 82.5 billion in the previous four years, an increase of 84 per cent. From an average increase of 4.6 per cent per annum during 1996-99, tax collection has grown at an average rate of almost 14 percent per annum during the next four years.

- Inflation at 3.1 per cent in 2002-03 was below the target of 4.0 percent. It is much lower than the average of 10 percent in the 1990s.

- Private sector credit is up by 19 per cent during 2002-03.

- Stock market remained buoyant during 2003, reaching the record level of 3100 (KSE index). It had been one of the world's best performers in the early 2000s [16].

- Industrial production is up by 8.0 per cent during JulyFebruary 2002-03.

- Investment is likely to rise to 16 per cent of GDP and economic growth is projected at 4.5 per cent - higher than the average of last three years (3.3 per cent during 19992000 to 2001-02).

- Both exports and imports have picked up despite uncertain global environment. Exports are up by 20 per cent and imports are up by 23 per cent during July-March 2002-03. 
- Pakistan's exports remained stagnated at around $\$ 8.0$ billion for six years (1994-95 to 1999-00), and at $\$ 9.0$ billion during the last two years and is expected to reach $\$ 10.5$ billion this year.

- Workers's remittances were around $\$ 1.0$ billion in 199899. This is likely to reach $\$ 4.3$ billion by end-June 2003 - all time high in the country's history.

- Foreign investment was as low as $\$ 403$ million in 199899. It has already reached $\$ 665$ million during JulyMarch 2002-03 and is expected to reach $\$ 1.0$ billion by the end of the current fiscal year.

- Most importantly, Pakistan's current account balance is in surplus. Pakistan has maintained current account deficit at around 5.0 per cent of GDP in the 1990s. This year the surplus is expected to reach $\$ 3.0$ billion or 4.0 per cent of GDP - a major turnaround in the economy.

- Strong build-up in reserves has strengthened Pakistani rupee viz US dollar. Exchange rate has appreciated by 11 per cent since July 3, 2001.

- Pakistan's external debt and foreign exchange liabilities which reached at unsustainable level by 1998-99 have started moving towards sustainability.

- Pakistan's total external debt and liabilities have declined by $\$ 3.0$ billion - from $\$ 38$ billion to $\$ 35$ billion. As percentage of GDP, the external debt and liabilities stood at 64 per cent in end-June 1999, declined to 60 per cent in end-June 2002, and projected to decline to 50.4 per cent by end-June 2003 .

- During this period, Pakistan added $\$ 9.4$ billion in its foreign exchange reserves. Hence, Pakistan has not only succeeded in reducing its debt liabilities by $\$ 3.0$ billion but has also succeeded in adding $\$ 9.4$ billion in its reserves.

- Pakistan's net debt and liabilities (total external debt and liabilities minus net reserves of the SBP) stood at $\$ 37$ billion in end-June 2000 and is expected to decline to $\$ 26$ billion by end-June 2003 - a reduction of $\$ 11.0$ billion in three years. As percentage of GDP, it is projected to decline from 60.7 per cent in end-June 2000 to 37.4 per cent by end-June 2003 .

- Pakistan's external debt burden has also declined significantly. External debt and foreign exchange liabilities as percentage of foreign exchange earnings stood at 335.4 percent in end-June 1999. It is expected to decline to 193 per cent by end-June 2003.

- Since, Pakistan's foreign exchange reserves have reached a comfortable level the government will be paying back expensive debt ahead of the time. This will reduce the country's debt burden even further.

The Take-off School contends [17] these macroeconomic improvements have set the stage for a return to a higher growth path. The acceleration started in 2001-02 when the growth rate in real GDP was was $3.1 \%$, up from 1.85 in the previous year. This was followed by rates of growth of 4.7 in 2002-03 and 7.5\% in 2003-04 (Table 1). This was the highest growth achieved since 1991-92. Based on these favorable developments the government has confidently forecast rising rates of growth over the next several years led by an expansion in textile manufacturing and construction.

In short, the Take-off School contends [18] that by 200203 macroeconomic stability had been achieved, both investment and growth were rising; interest rates were falling; inflation was low; private sector credit had picked up; both domestic and external debt levels were declining; exports were picking up, tax collection was rising, current account balance was in surplus; and the exchange rate was stable.

In turn this foundation paid great dividends in setting the stage for a major expansion of the economy in the 20032004 to 2006-2007 period [19]:

- Barring two years, GDP grew at an average rate of 3.8\% in the 1990s. It grew at an average of 7.0\% from 2003-04 through 2006-07.

- Investment recovered strongly to an average of almost $18.0 \%$ during the 2003-04 through 2006-07 period as opposed to $15.6 \%$ in $1998-99$.

- Unemployment declined as growth accelerated - from $8.3 \%$ in $2001-02$ to $6.2 \%$ in $2005-06$.

- In the six years from FY 2000 the economy created 10.4 million jobs.

- From 2000-01 through 2004-05 12.8 million people were brought out of poverty

- While inflation had been in double digits through most of the 1990s it averaged 5.6\% over the 20001-02 to 2006-07 period.

- While Pakistan sustained very large budget deficit in the 1990s, it had been halved in the last seven years (2001-02 through 2006-07).

- Due to the generous rescheduling of long-term debt obligations, the debt burden has eased to a manageable level, both in terms of external debt and total debt as a proportion to GDP. As a result, interest payments as a percent of total revenue declined from $51.2 \%$ in $1999-2000$ to $20.6 \%$ in 2006-07.

- The current account deficit remained high in the 1990s despite low economic growth. In contrast it has widened recently on account of strong economic activity.

- Pakistan's exchange rate appreciated from July 2001 through April 2004, depreciated a bit and since March 2005 has remained stable.

- Foreign exchange reserves which averaged around $\$ 1.5$ billion in the 1990s, reached $\$ 14.5$ billion in 2006-07.

- Foreign investment (FDI) has been rising steadily and sharply, with net FDI reaching $2.7 \%$ of GDP up from $0.7 \%$ in 2001-02.

- The country's credit rating has gradually improved in the Musharraf years, with the Moody's rating increasing from Caa1 in 2000 to B1 by the end of 2006.

- Remittances have shown steady increases from $\$ 1,087$ million in 2000-01 to \$5,500 in 2006-07.

- Public debt burden has declined sharply from $100.3 \%$ of GDP in 1999 to $52.0 \%$ in 2007. External debt as a percentage of foreign exchange earnings declined from 
Table 1. Economic Performance Under Pervez Musuarraf

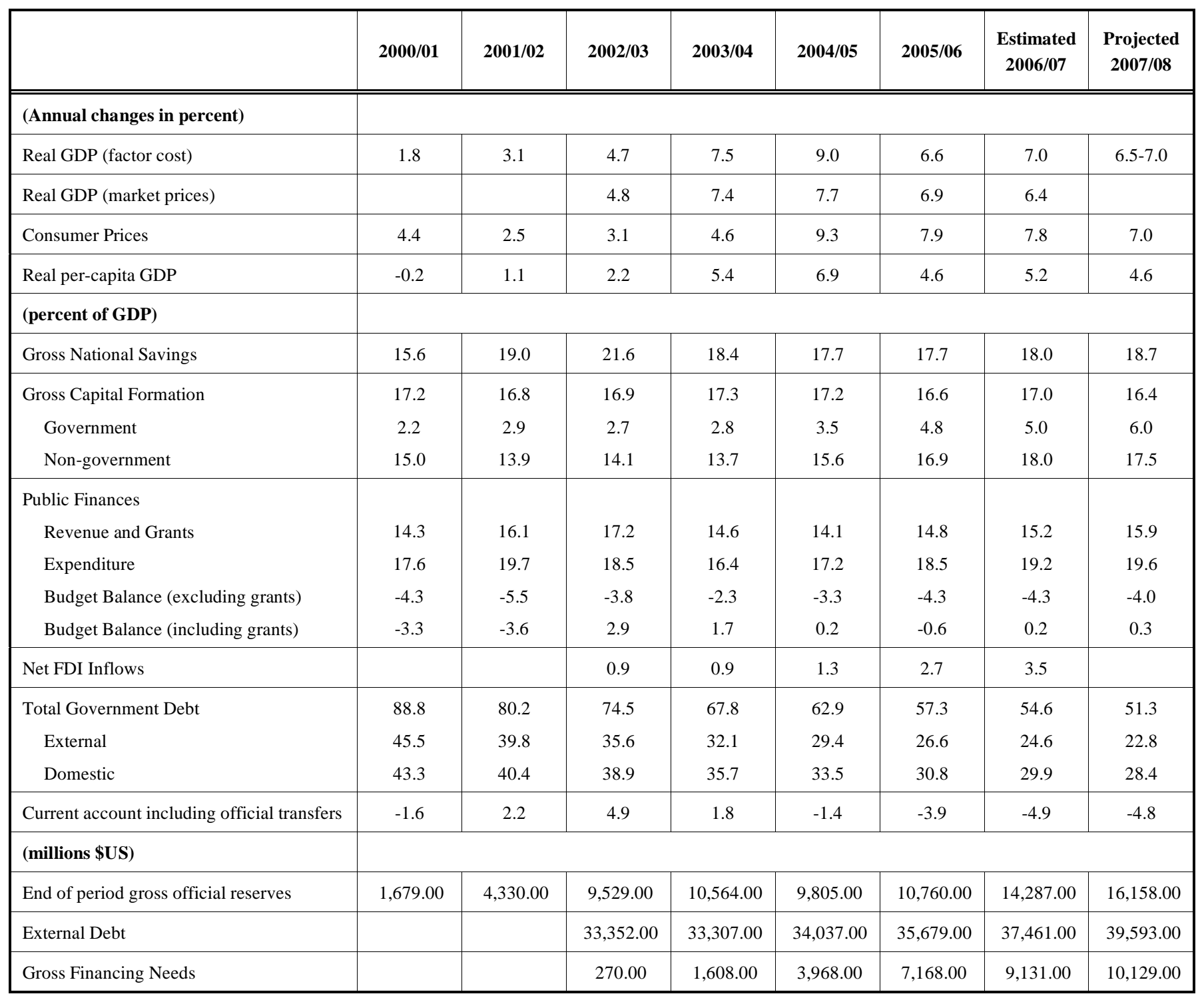

Source: International Monetary Fund Article IV Consultation, various issues

$347 \%$ in $1998-99$ to 180.5 in $2003-04$ and 111.2 in $2006-$ 07. External debt as a \% of GDP has declined by about one half since $2001-02$-- from $52.2 \%$ to 25.04 in 200607. Similarly debt servicing declined from $24.0 \%$ to 9.1 in 2005-06.

- The Karachi Stock Exchange has been one of the best performing among emerging markets. Market capitalization (as a percentage of GDP) has increased from $9.0 \%$ in 2000 to $35.3 \%$ in 2006 .

- As a result of its improved economic performance, Pakistan has been able to enter the international capital markets with three sovereign bonds issues. The country also extended its yield curve from 5-years to 30-years in just two years.

- Social development is also improving, and although the Human Development Index (HDI) value of 0.539 is low by international standards, it has risen fast over the last decade [20].
Vision 2030 [21] provides some detail of the longer-term changes envisaged by the Take-off School: [22]

Growing economically at a rate of around 7-8 percent per annum, Pakistan expects to join the ranks of middleincome countries, with a GDP of around USD 4,000 by 2030. This high growth rate would be sustained through developing its human resources and by developing the necessary physical and technological infrastructure.

The growth trajectory will gain momentum by the latent capacities of a sizeable middle class emerging in the development process. Besides sustaining high growth rates, benefits of growth are planned to be equitably distributed and poverty to be largely eliminated.

Vision 2030 acknowledges the forces of globalization and dispersion of information and technology, which are likely to dramatically change the scale and character of human enterprise. By 2030 human lives, workplaces, education, skills, trade and competition would stand 
transformed. We are determined to manage these global forces of change to our advantage.

Unfortunately for the take-off school things did not turn out the way proponents envisaged:

- The Planning Commission's ambitious expectation of a 7.5-8.0 percent GDP growth in 2007-08 did not occur and has been revised to $6.5 \%$. The reasons given have ranged from high international prices and inflation to a widening of the current account deficit and increased external debt.

- Rising prices of food items, combined with shortages of sugar, oil and flour, a looming power and gas crisis also worked to dampen the Musharraf economic expansion.

- Industrial growth has dipped to an average of 6 percent in the last several years with the critical textile sector showing signs of weakness.

- The agricultural sector still employing a large share of the workforce has not expanded as hoped resulting in increased food insecurity for large segments of the population.

In sharp contrast to the take-off school, the failed-takeoff school, while acknowledging the macroeconomic accomplishments of the Musharraf years, feels that the Musharraf strategy as actually applied did not adequately implement its economic strategy outlined above [23]. Instead its programs resulted in the creation of more distortions in the economy and society [24]. Combined with the country's latent governance and institutional deficiencies the result was the creation of serious imbalances throughout the economy. In turn, these imbalances are the source of much of the violence and discontent currently destabilizing the economy in particular and Pakistani society in general.

The leading proponent of this school is Shahid Javed Burki, a former Minister of Finance and World Bank Vice President who feels that despite early positive signs [25] the Government missed a golden opportunity in the 2005-06 budget to put the country on a new growth path [26]:

In sum, I believe that the budget has missed the opportunity to put forward a carefully thought-out strategy for sustaining growth, alleviating poverty, modernizing the economy and improving its efficiency. With growth having resumed this was a good opportunity to soberly reflect about the future and set the stage for the country's long-term development.

The failed-take off school views the main advantage of the Musharraf economic policies as implemented to be its pro-business orientation of allowing the private sector considerable room in which to operate. While this policy unleashed considerable entrepreneurial activity, it should have been accompanied by on-going improvements in governance, economic freedom and financial reform - all necessary requirements to complete the takeoff and continue on a path of sustained growth and development [27].

While some reforms in both areas did take place, there are major areas where governance and economic freedom actually deteriorated during this period. For example, the World Bank considers improved governance in five key areas as critical for increases in efficiency and higher invest- ment rates needed to achieve sustained growth (1) voice and accountability, (2) political stability, (3) government effectiveness, (4) regulatory quality, (5) rule of law and (6) control of corruption. Unfortunately, Pakistan's progress during the Musharraf years was spotty and inconsistent, especially in comparison with India's relatively steady progress during the same period (Table 2 ).

As anticipated there was a major decline in voice and accountability with Pakistan falling from a percentile rank of 27.4 in 1998 to 12.5 in 2006 . Political stability already in the bottom 10 percent declined even further ending up at 4.80 in 2006. On the other hand the government was able to forge significant gains in government effectiveness and regulatory quality, with smaller improvements in the rule of law. Unfortunately this progress was neutralized somewhat by increased corruption.

An even more inconsistent pattern occurred in areas related to economic freedom (Table 3). Pakistan scores [28] moderately well in fiscal freedom, business freedom, and labor freedom, but its only exceptionally high score is for limited government size. In line with its pro-business orientation, major gains were made during the Musharraf years in business freedom - the overall freedom to start, operate and close a business. The corporate tax rate is high, but tax revenue and government spending are low relative to GDP. Commercial registration and licensing are historically inefficient, but efforts to liberalize the business climate are producing results.

Trade liberalization progressed under Musharraf, but import bans and restrictions, import taxes, inconsistent standards administration, non-transparent government procurement, export subsidies weak enforcement of intellectual property rights and corruption add considerably to the cost of trade. The net effect appears to have undermined the government's efforts at becoming more integrated into the world economy (Table 4). Between 2003 and 2007 Pakistan declined from the $50^{\text {th }}$ most globalized country to $63^{\text {rd }}$. This deterioration in relative globalization was across all dimensions of globalization, economic, personal, technological and political. To the country's credit, the declines in some areas were not as great as those experienced by its South-Asia neighbors, India, Sri Lanka and Bangladesh.

Unfortunately, in the other areas of economic freedom, Pakistan suffered significant reversals during the Musharraf years. Major declines occurred in investment freedom, financial freedom property rights and freedom from corruption during this period. The lack of significant financial reform during the Musharraf years is confirmed by the country's rankings in the Milken Institute's Capital Access Index (Table 5). This index indicates measures the extent to which countries are creating the conditions necessary for firms to raise capital. Specifically countries are ranked in terms of how well they support economic activity by providing businesses with access to capital, both domestic and foreign [29].

For the index as a whole, Pakistan ranked in $65^{\text {th }}$ in 2003 - that is firms in 65 countries had better access to capital than those in Pakistan. By 2007 the country had fallen to $72^{\text {nd }}$ place. Even more troubling the Milken assessment of the country's macroeconomic environment, the focus of the Musharraf programs had achieved only marginal improve- 
Table 2. Governance Comparisons: Pakistan and India

\begin{tabular}{|c|c|c|c|c|c|c|c|c|c|}
\hline & 2006 & 2005 & 2004 & 2003 & 2002 & 2000 & 1998 & 1996 & $\begin{array}{c}\% \text { Change } \\
\text { 1998-06 }\end{array}$ \\
\hline \multicolumn{10}{|l|}{ Voice and Accountability } \\
\hline \multicolumn{10}{|l|}{$\underline{\text { Pakistan }}$} \\
\hline Estimate $(-2.5$ to +2.5$)$ & -1.17 & -1.08 & -1.17 & -1.25 & -1.23 & -1.39 & -0.74 & -0.73 & \\
\hline Percentile Rank (0-100) & 12.50 & 15.90 & 16.30 & 13.00 & 14.40 & 9.10 & 27.40 & 27.30 & -54.38 \\
\hline \multicolumn{10}{|l|}{$\underline{\text { India }}$} \\
\hline Estimate $(-2.5$ to +2.5$)$ & 0.35 & 0.40 & 0.39 & 0.32 & 0.40 & 0.28 & 0.34 & 0.12 & \\
\hline Percentile Rank (0-100) & 58.20 & 61.10 & 60.60 & 56.70 & 59.10 & 57.20 & 58.20 & 52.20 & 0.00 \\
\hline \multicolumn{10}{|l|}{ Political Stability } \\
\hline \multicolumn{10}{|l|}{$\underline{\text { Pakistan }}$} \\
\hline Estimate $(-2.5$ to +2.5$)$ & -1.92 & -1.71 & -1.72 & -1.70 & -1.58 & -0.92 & -1.28 & -1.45 & \\
\hline Percentile Rank (0-100) & 4.80 & 5.30 & 5.80 & 5.80 & 9.10 & 18.30 & 12.00 & 9.10 & -60.00 \\
\hline \multicolumn{10}{|l|}{$\underline{\text { India }}$} \\
\hline Estimate $(-2.5$ to +2.5$)$ & -0.84 & -0.79 & -0.94 & -1.25 & -1.01 & -0.66 & -0.83 & -1.12 & \\
\hline Percentile Rank (0-100) & 22.10 & 22.60 & 20.20 & 13.90 & 17.80 & 25.00 & 21.20 & 14.90 & 4.25 \\
\hline \multicolumn{10}{|c|}{ Government Effectiveness } \\
\hline \multicolumn{10}{|l|}{$\underline{\text { Pakistan }}$} \\
\hline Estimate $(-2.5$ to +2.5$)$ & -0.51 & -0.54 & -0.51 & -0.53 & -0.61 & -0.65 & -0.63 & -0.52 & \\
\hline Percentile Rank (0-100) & 34.10 & 33.60 & 35.10 & 35.50 & 30.30 & 28.00 & 26.50 & 33.60 & 28.68 \\
\hline \multicolumn{10}{|l|}{ India } \\
\hline Estimate $(-2.5$ to +2.5$)$ & -0.04 & -0.12 & -0.06 & -0.05 & -0.11 & -0.14 & -0.16 & -0.19 & \\
\hline Percentile Rank (0-100) & 54.00 & 51.20 & 55.90 & 57.80 & 55.50 & 52.60 & 53.10 & 50.70 & 1.69 \\
\hline \multicolumn{10}{|l|}{ Regulatory Quality } \\
\hline \multicolumn{10}{|l|}{$\underline{\text { Pakistan }}$} \\
\hline Estimate $(-2.5$ to +2.5$)$ & -0.39 & 0.61 & -0.88 & -0.74 & -0.81 & -0.72 & -0.51 & -0.31 & \\
\hline Percentile Rank (0-100) & 38.50 & 27.30 & 18.00 & 22.00 & 20.00 & 21.50 & 26.30 & 31.20 & 46.39 \\
\hline \multicolumn{10}{|l|}{$\underline{\text { India }}$} \\
\hline Estimate $(-2.5$ to +2.5$)$ & -0.15 & -0.24 & -0.38 & -0.36 & -0.35 & -0.13 & -0.28 & 0.02 & \\
\hline Percentile Rank (0-100) & 48.30 & 46.80 & 40.00 & 41.00 & 41.50 & 45.40 & 34.60 & 44.40 & 39.60 \\
\hline \multicolumn{10}{|l|}{ Rule of Law } \\
\hline \multicolumn{10}{|l|}{ Pakistan } \\
\hline Estimate $(-2.5$ to +2.5$)$ & -0.82 & -0.86 & -0.86 & -0.81 & -0.76 & -0.80 & -0.79 & -0.59 & \\
\hline Percentile Rank (0-100) & 24.30 & 21.90 & 20.00 & 25.70 & 27.10 & 27.10 & 21.90 & 31.90 & 10.96 \\
\hline \multicolumn{10}{|l|}{$\underline{\text { India }}$} \\
\hline Estimate $(-2.5$ to +2.5$)$ & 0.17 & 0.12 & 0.00 & -0.01 & -0.02 & 0.19 & 0.15 & 0.26 & \\
\hline Percentile Rank (0-100) & 57.10 & 56.20 & 52.90 & 52.40 & 53.30 & 58.10 & 58.10 & 61.00 & -1.72 \\
\hline \multicolumn{10}{|l|}{ Control of Corruption } \\
\hline \multicolumn{10}{|l|}{$\underline{\text { Pakistan }}$} \\
\hline Estimate $(-2.5$ to +2.5$)$ & -0.93 & -1.03 & -1.03 & -0.74 & -0.83 & -0.76 & -0.88 & -1.04 & \\
\hline Percentile Rank (0-100) & 18.00 & 15.50 & 12.60 & 28.20 & 24.80 & 25.70 & 18.40 & 12.60 & -2.17 \\
\hline \multicolumn{10}{|l|}{$\underline{\text { India }}$} \\
\hline Estimate $(-2.5$ to +2.5$)$ & -0.21 & -0.33 & -0.37 & -0.38 & -0.41 & -0.33 & -0.27 & -0.36 & \\
\hline Percentile Rank (0-100) & 52.90 & 46.60 & 45.60 & 44.70 & 42.20 & 45.60 & 47.60 & 40.30 & 11.13 \\
\hline
\end{tabular}

Source: Compiled from: World Bank, Governance Matters 2007: Worldwide Governance Indicators, 1996-2006. 
Table 3. Changes in Economic Freedom During the Musharraf Years

\begin{tabular}{|c|c|c|c|c|c|c|c|c|c|c|c|c|}
\hline Country & 2008 & 2007 & 2006 & 2005 & 2004 & 2003 & 2002 & 2001 & 2000 & 1999 & 1998 & $\begin{array}{c}\text { \% Change } \\
1998-08\end{array}$ \\
\hline \multicolumn{13}{|c|}{ Economic Freedom Summary Score } \\
\hline Pakistan & 56.8 & 58.2 & 59.5 & 53.3 & 53.2 & 55.5 & 53.7 & 51.9 & 55.9 & 53.4 & 57.9 & -1.8 \\
\hline Bangladesh & 44.9 & 47.8 & 54.4 & 47.0 & 49.7 & 49.0 & 46.7 & 47.2 & 47.1 & 48.2 & 43.9 & 2.2 \\
\hline India & 54.2 & 55.6 & 52.3 & 54.4 & 51.8 & 51.6 & 51.4 & 47.1 & 45.7 & 48.1 & 44.9 & 20.8 \\
\hline Sri Lanka & 58.3 & 59.3 & 60.1 & 58.6 & 59.9 & 60.9 & 62.3 & 64.3 & 61.6 & 62.7 & 66.1 & -11.8 \\
\hline \multicolumn{13}{|c|}{ Business Freedom (Regulation) } \\
\hline Pakistan & 70.8 & 70.9 & 72.1 & 50 & 50 & 50 & 30 & 30 & 30 & 30 & 30 & 136.0 \\
\hline Bangladesh & 55.3 & 64.3 & 68.0 & 10 & 10 & 10 & 10 & 10 & 10 & 10 & 10 & 453.0 \\
\hline India & 50.0 & 49.6 & 49.9 & 30 & 30 & 30 & 30 & 30 & 30 & 30 & 30 & 66.6 \\
\hline Sri Lanka & 71.5 & 69.2 & 69.2 & 50 & 50 & 50 & 50 & 50 & 50 & 50 & 70 & 2.1 \\
\hline \multicolumn{13}{|c|}{ Trade Freedom } \\
\hline Pakistan & 65.2 & 53.6 & 54.0 & 49.6 & 50.6 & 59.2 & 54.0 & 44.4 & 58.0 & 44.0 & 50.0 & 30.4 \\
\hline Bangladesh & 0.0 & 0.0 & 48.2 & 54.0 & 58.0 & 58.0 & 50.6 & 48.8 & 52.0 & 54.0 & 0.0 & \\
\hline India & 51.0 & 51.2 & 24.0 & 58.0 & 43.6 & 43.0 & 41.9 & 45.6 & 39.6 & 44.0 & 4.4 & 1059.1 \\
\hline Sri Lanka & 69.6 & 66.6 & 66.4 & 71.6 & 65.6 & 65.2 & 67.0 & 65.2 & 66.0 & 63.0 & 76.0 & -8.4 \\
\hline \multicolumn{13}{|c|}{ Fiscal Freedom } \\
\hline Pakistan & 79.1 & 82.0 & 80.9 & 79.8 & 78.8 & 77.2 & 82.6 & 88.0 & 88.0 & 85.7 & 78.3 & 1.0 \\
\hline Bangladesh & 84.0 & 89.4 & 89.4 & 89.4 & 84.8 & 84.8 & 84.9 & 84.8 & 84.8 & 84.8 & 82.0 & 2.5 \\
\hline India & 75.7 & 84.8 & 84.9 & 83.6 & 83.1 & 85.5 & 85.5 & 85.6 & 85.6 & 85.5 & 78.3 & -3.3 \\
\hline Sri Lanka & 73.5 & 85.7 & 85.7 & 85.7 & 86.6 & 82.3 & 82.2 & 82.3 & 81.9 & 81.8 & 81.6 & -9.9 \\
\hline \multicolumn{13}{|c|}{ Government Size } \\
\hline Pakistan & 90.1 & 89.3 & 88.7 & 88.1 & 85.1 & 81.7 & 85.1 & 88.9 & 74.9 & 72.2 & 73.8 & 22.0 \\
\hline Bangladesh & 93.2 & 91.5 & 93.2 & 93.1 & 93.6 & 93.0 & 92.1 & 92.5 & 88.7 & 93.6 & 92.4 & 0.8 \\
\hline India & 73.5 & 89.0 & 74.3 & 75.0 & 75.2 & 70.8 & 76.1 & 74.6 & 72.9 & 86.1 & 85.4 & -13.9 \\
\hline Sri Lanka & 81.7 & 85.7 & 91.3 & 81.6 & 80.1 & 81.7 & 82.4 & 81.9 & 81.6 & 75.7 & 70.7 & 15.6 \\
\hline \multicolumn{13}{|c|}{ Monetary Freedom } \\
\hline Pakistan & 72.2 & 72.0 & 74.5 & 74.0 & 78.4 & 78.1 & 76.6 & 75.4 & 72.3 & 68.8 & 69.0 & 4.6 \\
\hline Bangladesh & 68.9 & 68.7 & 74.9 & 76.3 & 78.9 & 80.8 & 72.7 & 68.6 & 68.1 & 71.0 & 71.1 & -3.0 \\
\hline India & 70.3 & 77.2 & 77.6 & 77.4 & 77.1 & 77.6 & 70.8 & 68.3 & 63.7 & 67.2 & 65.6 & 7.1 \\
\hline Sri Lanka & 65.4 & 69.8 & 72.7 & 72.3 & 69.6 & 68.7 & 79.4 & 79.1 & 75.0 & 74.0 & 77.0 & -15.1 \\
\hline Pakistan & 40 & 50 & 50 & 30 & 50 & 50 & 50 & 50 & 70 & 70 & 70 & -42.9 \\
\hline Bangladesh & 20 & 30 & 30 & 30 & 50 & 50 & 50 & 50 & 50 & 50 & 50 & -60.0 \\
\hline India & 40 & 40 & 50 & 50 & 50 & 50 & 50 & 30 & 30 & 30 & 50 & -20.0 \\
\hline Sri Lanka & 30 & 30 & 30 & 50 & 50 & 50 & 50 & 50 & 50 & 50 & 50 & -40.0 \\
\hline
\end{tabular}


(Table 3) contd....

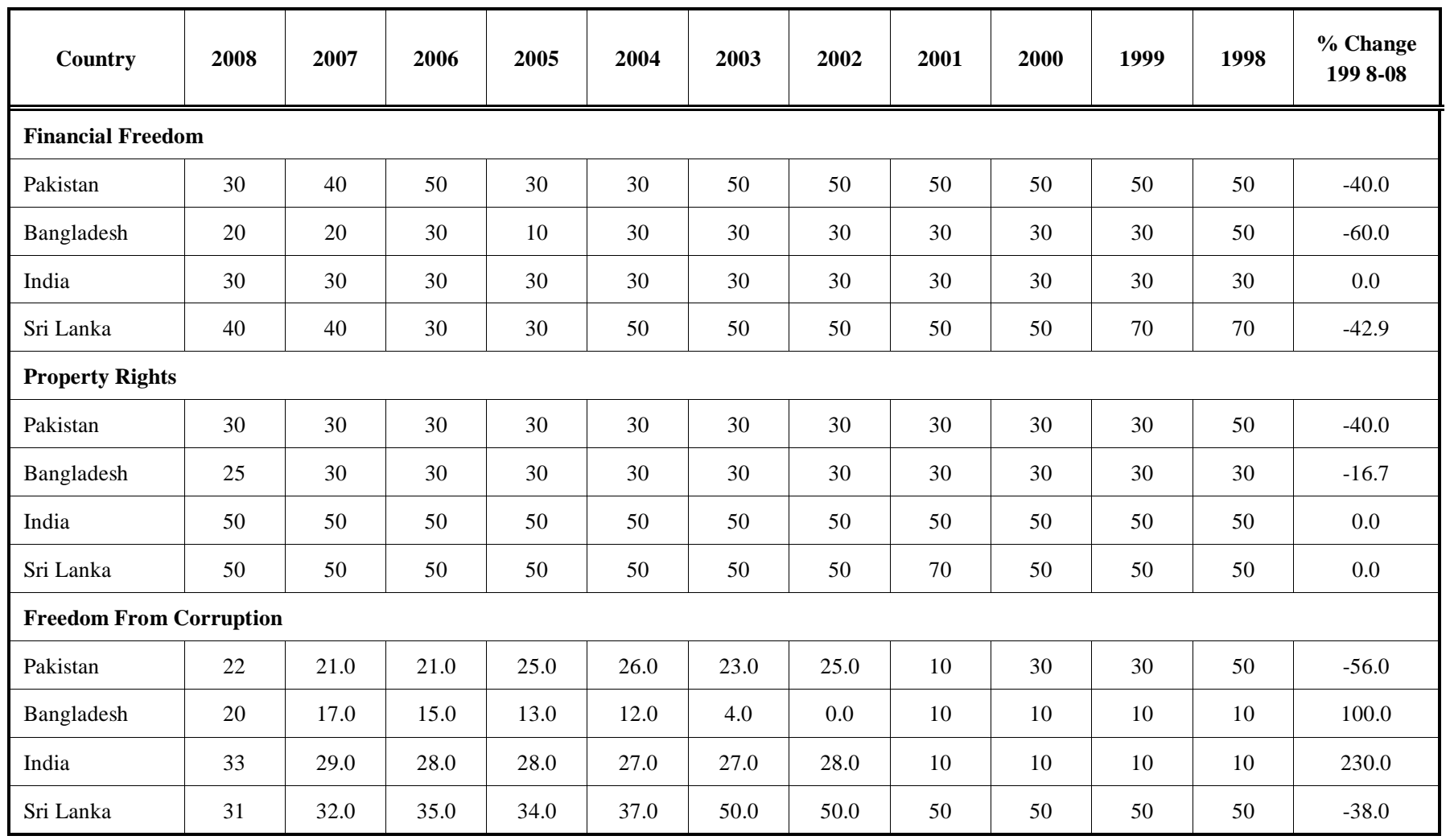

Source: Heritage Foundation, Economic Freedom of the World, various issues.

ments in recent years, improving its ranking from $112^{\text {th }}$ place in 2005 to $104^{\text {th }}$ by 2007 . In equity market development the country fell from $15^{\text {th }}$ place in 2005 to $40^{\text {th }}$ by 2007 . A similar situation occurred in bond market development where the country declined from $52^{\text {nd }}$ place in 2005 to $63^{\text {rd }}$ in 2007 . No doubt the failure to reform and develop the financial system has contributed to the country's relatively low savings rate and its inability to channel investment into the most productive sectors of the economy - two critical areas needed to sustain rates of growth in the 6-8\% range.

The government's economic strategy, together with the institutional deficiencies noted above are seen [30] by the failed take-off school to lead to a number of specific factors likely to increasingly constrain growth. While some of these factors are clearly the result of institutional or governance deficiencies, others appear to be more related to poor decision making on the part of the Musharraf administration compounded by the fact that there is a tendency for authoritarian regimes to be less responsive than democracies to problems facing the average citizen. Behind the numbers and trends one gets a better idea of the dynamics of the Musharraf era.

First, while the country has been able to attract more foreign investment most of these funds did not go into the export sector but instead went into activities satisfying domestic demand. This will produce problems for the future since it will likely increase pressure on the external accounts. This stems directly from the lack of reforms in the trade area limiting the extent to which has been integrated into the world economy.
Second, the regime also failed to put in place a strategy that takes care of the supply bottlenecks that would inevitably result from a sharp increase in GDP. In particular the government failed to plan to meet the supply-demand gap in the energy sector for both electricity and gas. By 2006-7 the situation had developed into a full blown crisis. Electricity shortages caused many firms to maintain shorter hours with distinct losses in output. There was mounting concern that the power shortage would affect the productive capacity and export performance of the country.

In all fairness to the Musharraf administration the energy crisis did not emerge all of a sudden and it is the result of neglecting the supply side for the past few decades. Beginning in the early 1980s, the gap between the consumption and generation of electricity steadily expanded, but no augmenting measures were initiated [31]. Nor until very recently were the energy problems facing the country examined in any sort comprehensive way [32].

On the other hand the Musharraf administration has done little to help broad In an exhaustive study of the country's infrastructure situation, the World Bank was forced to conclude [33].

Pakistan suffers from a dearth of infrastructure in the water, irrigatin, power, and transport sectors; infrastructure which is essential for sustained growth and competitiveness both in the local and international markets. The gaps between demand and supply in these sectors are alarming. Unless plans are put in place urgently, these critical shortages could lead to increased social discontent and disharmony amongst the federation and the provinces. 
Table 4. Pakistan: Patterns of Relative Globalization

\begin{tabular}{|c|c|c|c|c|c|c|}
\hline Pakistan & 63 & 56 & 50 & 46 & 50 & -26.0 \\
\hline India & 71 & 61 & 61 & 61 & 56 & -26.8 \\
\hline Sri Lanka & 56 & 46 & 43 & 51 & 44 & -27.3 \\
\hline \multicolumn{7}{|l|}{ Economic Dimension } \\
\hline Pakistan & 63 & 60 & 53 & 55 & 60 & -5.0 \\
\hline India & 66 & 59 & 59 & 61 & 61 & -8.2 \\
\hline \multicolumn{7}{|l|}{ Personal Dimension } \\
\hline Pakistan & 42 & 34 & 33 & 36 & 37 & -13.5 \\
\hline India & 59 & 51 & 48 & 53 & 49 & -20.4 \\
\hline Bangladesh & 43 & 37 & 35 & 43 & 39 & -10.3 \\
\hline Sri Lanka & 32 & 27 & 26 & 34 & 28 & -14.3 \\
\hline \multicolumn{7}{|c|}{ Technological Dimension } \\
\hline Pakistan & 60 & 59 & 59 & 59 & 56 & -7.1 \\
\hline India & 63 & 57 & 56 & 55 & 54 & -16.7 \\
\hline India & 69 & 60 & 60 & 57 & 14 & -392.9 \\
\hline Bangladesh & 54 & 49 & 53 & 35 & 24 & -125.0 \\
\hline Sri Lanka & 60 & 58 & 56 & 60 & 55 & -9.1 \\
\hline
\end{tabular}

Source, Foreign Policy Index of Globalization, various issues.

Third, the tax base remains narrow and rather inflexible. The Musharraf government failed to realize that major fiscal reforms were needed to prevent growth from widening income inequalities and failing to pull large segments of the population out of poverty [34].

- Only around $2 \%$ of the population pays direct income taxes with the bulk of the tax burden falling on the poor, the salaried class and the business sector. Around $70 \%$ of tax revenue is generated by indirect taxes that are generally considered regressive.

- There is a mismatch between sectoral contributions to growth and tax revenue. Agriculture contributes $22.5 \%$ of GDP, but only $1.2 \%$ of tax revenue as compared with manufacturing, which contributes $18 . \%$ of GDP, but $62 \%$ of revenue from taxes.
- Tax evasion is widespread. The exemption of agricultural incomes from direct income taxes is believed to be an important source of tax evasion, for example, enabling industrialists to hide income by buying agricultural property.

- Agricultural incomes have subject to tax exemptions since 1886. The prime beneficiaries of agricultural tax exemption are large landowners. Approximately $40 \%$ of the labor force is employed in the agricultural sector, but over half of the rural population is landless.

In addition to paying more than their fair share of taxes, there is a reason why the poor did not benefit as much from the Musharraf economic expansion. This was due to the fact that growth came from the sectors which did not provide much employment to lower income groups. Much of the 
Table 5. Pakistan's Progress in Financial Development

\begin{tabular}{|c|c|c|c|c|c|c|}
\hline & \multicolumn{2}{|c|}{2007} & \multicolumn{2}{|c|}{2006} & \multicolumn{2}{|c|}{2005} \\
\hline & Rank & Index & Rank & Index & Rank & Index \\
\hline Over-all Capital Access Index & & {$[4.71]$} & & {$[4.64]$} & & {$[4.59]$} \\
\hline Pakistan & 72 & 4.06 & 65 & 4.23 & 74 & 3.79 \\
\hline India & 41 & 5.50 & 46 & 5.18 & 53 & 4.58 \\
\hline Sri Lanka & 70 & 4.11 & 66 & 4.21 & 64 & 4.27 \\
\hline Bangladesh & 92 & 3.24 & 97 & 3.32 & 87 & 3.43 \\
\hline Macroeconomic Environment & & {$[6.03]$} & & {$[5.95]$} & & {$[6.07]$} \\
\hline Pakistan & 104 & 4.25 & 112 & 3.75 & 112 & 3.75 \\
\hline India & 60 & 6.00 & 71 & 5.50 & 76 & 5.50 \\
\hline Sri Lanka & 67 & 5.50 & 84 & 5.00 & 64 & 5.83 \\
\hline Bangladesh & 89 & 4.83 & 96 & 4.67 & 64 & 5.83 \\
\hline Institutional Environment & & {$[5.36]$} & & {$[5.40]$} & & {$[5.31]$} \\
\hline Pakistan & 61 & 5.18 & 70 & 4.82 & 79 & 4.41 \\
\hline India & 63 & 5.12 & 54 & 5.29 & 79 & 4.41 \\
\hline Sri Lanka & 78 & 4.65 & 74 & 4.71 & 65 & 4.82 \\
\hline Bangladesh & 109 & 3.35 & 97 & 3.88 & 98 & 3.71 \\
\hline Financial and Banking Institutions & & {$[4.58]$} & & {$[4.56]$} & & {$[4.66]$} \\
\hline Pakistan & 76 & 3.44 & 47 & 5.00 & 64 & 4.40 \\
\hline India & 39 & 5.78 & 50 & 4.90 & 58 & 4.60 \\
\hline Sri Lanka & 48 & 4.89 & 62 & 4.30 & 48 & 5.00 \\
\hline Bangladesh & 79 & 3.33 & 62 & 4.30 & 72 & 4.00 \\
\hline Equity Market Development & & {$[3.39]$} & & {$[3.48]$} & & {$[3.57]$} \\
\hline Pakistan & 40 & 4.67 & 33 & 5.67 & 15 & 7.33 \\
\hline India & 21 & 6.33 & 25 & 6.17 & 20 & 6.83 \\
\hline Sri Lanka & 63 & 3.17 & 43 & 4.67 & 46 & 4.50 \\
\hline Bangladesh & 60 & 3.33 & 72 & 2.33 & 66 & 3.00 \\
\hline Bond Market Development & & {$[3.45]$} & & {$[3.46]$} & & {$[2.52]$} \\
\hline Pakistan & 63 & 2.75 & 43 & 4.75 & 52 & 2.50 \\
\hline India & 35 & 5.25 & 29 & 5.75 & 46 & 2.75 \\
\hline Sri Lanka & 65 & 2.50 & 51 & 4.00 & 55 & 2.00 \\
\hline Bangladesh & 75 & 1.50 & 68 & 1.75 & 75 & 0.00 \\
\hline Alternative Sources of Capital & & {$[3.07]$} & & {$[2.47]$} & & {$[2.86]$} \\
\hline Pakistan & 69 & 2.00 & 61 & 1.75 & 82 & 1.00 \\
\hline India & 29 & 5.00 & 33 & 3.75 & 42 & 3.50 \\
\hline Sri Lanka & 73 & 1.75 & 61 & 1.75 & 74 & 1.50 \\
\hline Bangladesh & 92 & 0.75 & 86 & 0.75 & 91 & 0.50 \\
\hline
\end{tabular}




\begin{tabular}{|c|c|c|c|c|c|c|}
\hline & \multicolumn{2}{|c|}{2007} & \multicolumn{2}{|c|}{2006} & \multicolumn{2}{|c|}{2005} \\
\hline & Rank & Index & Rank & Index & Rank & Index \\
\hline International Funding & & {$[4.13]$} & & {$[4.06]$} & & {$[4.22]$} \\
\hline Pakistan & 70 & 4.17 & 67 & 3.67 & 85 & 3.75 \\
\hline India & 42 & 4.83 & 53 & 4.25 & 40 & 4.83 \\
\hline Sri Lanka & 89 & 3.42 & 86 & 3.08 & 102 & 3.08 \\
\hline Bangladesh & 95 & 3.00 & 94 & 2.67 & 105 & 2.92 \\
\hline
\end{tabular}

Data from: Milken Institute, Capital Market Access, various issues (Santa Monica: Milken Institute).

[ ] = mean value

Macroeconomic Environment captures the extent to which a country's macroeconomic environment is favorable to running and financing a business.

Institutional environment reflects the extent to which a country has the institutions needed to support and enhance business financing activities.

Financial and Banking Institutions measures the level of involvement of deposit-taking institutions in financing business.

Equity Market Development reflects the extent to which financing of business operations is important for a given country.

increase in GDP came from the sectors which returned high rewards to the investors but in which the share of wages was relatively low. Real estate development was one of the important sectors of the economy as was the modern service sector. Neither, at least in the context of Pakistan, generated employment and income for the poorer segments of the population [35].

Another area where the Musharraf administration failed to make any progress at reform was the country's sprawling military industrial complex or Milbus. Over the years, Pakistan's military has expanded its holding of industries, properties and foundations. These organizations guarantee the armed forces both organizational autonomy and a regular flow of resources from the public and private sectors - often to the enrichment of senior officers, both on-duty and retired.

The military has come to control 11.58 million acres of state land or $12 \%$ of the total. Much of this is rented at very low fees to its personnel. The estimated total wealth of this sector varies but may be as high as $\$ 100$ billion and no doubt expanded even further during the Musharraf era. From an economic perspective these activities are nothing like the leading industries in Rostow's take-off stage. Instead, Milbus places a tremendous drag on any economic expansion [36]:

The financial inefficiency of these business ventures places a financial cost on the state. Some of the financial burden...is borne by the state by providing financial guarantees or providing loans to the military controlled companies. The financial aid given to these foundations is detrimental to the growth of a free-market economy. ...The linkage between the state and tese companies, and its impact on the overall business environment, is not the only opportunity cost. The presence of the military in the private sector or in profit-making activities results in encouraging crony capitalism in the country. This creates a situation where the dominant cflasses collude with the military to benefit from the state and its resources at the risk of ignoring all those who are not part of the 'elite consensus'.
Finally, under Musharraf, the country became vulnerable to reductions in external capital flows. The vulnerability of the economy to external flows is revealed by the data on investments and the sources for financing it. During the Musharraf period, efforts to increase private investment achieved some success with the rate of investment increasing by about a third -- from 13.9 per cent of GDP in 2001-02 to 18.0 per cent in 2006-07 (Table 1). However during this period gross national savings declined from 19.0 percent of GDP to 18.7 percent. This suggests that the economy, contrary to government statements is becoming increasingly dependent on foreign capital. Given the country's political instability and lack of significant progress in governance and economic reforms, this further increases the country's vulnerability to a fall-off in foreign capital. At this point any major reduction in foreign capital inflows could precipitate a sharp economic down-turn [37].

As Burki observes, [38] Pakistan will face severe competition for foreign capital and may be less competitive in this regard unless major changes occur:

One of the positive features of the way the Musharraf government managed the economy is to have made it attractive for some foreign investors. But Pakistan has not become an important destination for investors as India has over the last decade. India offers the promise of political stability, a legal system that can protect investors, a highly trained workforce, and a fairly large rate of domestic savings. It also has a large domestic market which is of interest to foreign companies.

Unless major reforms overcome deficiencies in governance, economic freedom, and capital market access, the failed take off school is skeptical the country will be able to maintain or even approach the growth rates obtained in the last several years-limitations in these areas will increasingly constrain investment and efficiency thus producing an increasingly heavy drag on the economy. In short, the country will fail in its efforts to take-off because it did not create the institutional and governance conditions necessary for a rapid and prolonged expansion of the economy. 
This conclusion is reinforced by recent empirical evidence [39] that suggests Pakistan's defense expenditures have a negative impact of economic growth due largely to the fact that the country's allocations to the military are high relative to the levels of governance attained to date. This remained the case throughout the Musharraf years. The implications of these finding for the country's take off are clear[40]:

Our findings and the literature suggest that the opportunity cost of these increased (defense) expenditures will be relatively high in the long run. Pakistan's infrastructure will continue to deteriorate, further degrading its ability to generate economic growth and increasing domestic instability. This destructive cycle of increased defense expenditures - reduced economic growth can be mitigated however, if Pakistan is able to increase institutional capacity and quality.

Given the lack of institutional development in such key areas as control of corruption other types of government expenditure may have also hit diminishing returns of this sort and thus further contributed to the slowdown of the overall economy beginning in 2007. In most countries the slowing of growth does not necessarily cause political problems unless the previous gains from growth were inequitably distributed. Unfortunately for the Musharraf administration this seems to have been the case. A pro-business policy bias, lack of democratic feed-back and an authoritarian-style of policymaking are also not conducive to broad-based development [41]:

The government headed by General Pervez Musharraf was confident that its economic record, with GDP increasing at an unprecedented seven percent a year for five years would be appreciated by the majority of the citizenry. Its confidence was so great that it was not prepared to listen to those who were sending signals of caution. Many commentators ......kept on reminding Islamabad that macro numbers were hiding many micro problems. But Islamabad was in no mood to listen and has paid a price by sending the country into a spiral of political discontent that has gone on for nine months.

While no detailed studies of income distribution are available for the last several years, Burki feels confident that around 10 million belong to the class that has benefitted from economic growth and restructuring, 25 million would have entered the system had it not been disrupted and 45 million who were completely ignored [42]. Furthermore he notes a regional dimension of inequality has emerged from the Musharrf era. The benefits of growth were largely confided to central and northern Punjab and such large cities as Islamabad, Lahore, Karachi, Faisalabad and Gujranwala [43].

The failed-takeoff school contends that Pakistan's political history suggests that economic developments can create great political instability. This happened towards the end of previous failed take-offs. The first was associated with President Ayub Khan in the 1960s when there was widespread perception that the benefits of the extraordinary economic expansion during this period went to a very limited number of prominent families [44]. There is no doubt that the authoritarian growth model developed in the 1960s also created a wide disparity of income between the two regions of Pakistan, East Pakistan and West Pakistan leading to the country's breakup. In the second case, similar, but less dramatic, changes took place in the late 1980s at the end of the Zia authoritarian era.

In both cases the aggrieved resorted to violence to achieve their goals [45]. Fortunately for the country, this time they simply voted.

\section{CONCLUSIONS}

Given the difficulty, the country has had over the years in sustaining high rates of growth, the Musharraf programs and reforms will no doubt be ultimately judged on the quality of the institutions put in place. Are these institutions capable of fairly resolving many of the conflicts that have repeatedly derailed the economy? Will they permit continuity in economic policy? Will they strengthen democracy, enabling all segments of society better access to public services and opportunities? Will they enable the country to finally have a successful economic transition to high sustained growth?

The pro-administration, take-off school contends that through its macroeconomic stabilization policies and progress in economic and governance reforms the country is now positioned to sustain high rates of economic growth the previous boom bust pattern of growth made a thing of the past - the recent slow-down of the economy simply reflects the political uncertainty prior to the election. Now that that has been resolved the country will quickly resume the rapid pace of growth of the last several Musharraf years.

The failed take-off explanation while acknowledging the many economic successes of the Musharraf years contended that the administration did not make enough progress in governance and supporting growth enhancing institutions for growth to be sustainable. Even worse, the Musharraf government's polices and actions not only failed to address mounting constraints, but in many cases only served to aggravate them.

From the vantage point of early 20008 it may be premature to provide a final judgment of the Musharraf economic policies. However a large body of evidence points toward their failure. Certainly, dissatisfaction with the performance of the economy was one of the main reasons for his fall from power and while some of his reforms have yet to be completed they are unlikely to create the conditions for high sustained grates of growth. Or, as so eloquently put by Burki [46]:

.... the conditions just don't exist in Pakistan which can support a high rate of economic growth, alleviate poverty and improve the distribution of income. We don't save enough from our national income to accumulate capital. We have not trained our large and growing workforce to help modernize the economy and take advantage of the window of opportunity that exists as a result of falling rates of fertility in the developed world.

By election time in early 2008, these economic subtleties as well as the harsh realities of rising food and energy prices were becoming more and more apparent to broad segments of the Pakistani electorate. 


\section{REFERENCES}

[1] Simon Robinson, "Food Price Hikes Roil Pakistan," Time, February 27,2008 . http://www.time.com/time/printout/0,8816,1717596, 00.html

[2] See Hilton Root, "The Political Economy of State Failure," The Milken Institute Review Spring Quarter 2005, pp. 65-74 and Robert Looney, "Pakistan's Economy: Achievements, Progress, Constraints and Prospects," in Hareez Malik, Pakistan: Founder's Aspirations and Today's Realities (Oxford: Oxford University Press, 2001) for a detailed description of this period.

[3] Unemployment more than doubled during the 1990s. See Edward Gardner, "Wanted More Jobs," Finance and Development, 40:1 (March 2003) http://www.imf.org/external/pubs/ft/fandd/2003/03/ gard.htm

[4] Detailed in: Poverty in Pakistan: Vulnerabilities, Social Gaps, and Rural Dynamics (Washington: World Bank, October 28, 2002).

[5] "President Hopes Government Will Benefit from His Policies," Dawn, November 17, 2002. http://www.dawn.com/2002/11/17/ top2.htm

[6] "Bread and Butter Politics," The Guardian, February 20, 2008.

[7] Robert Hathaway, "The Devil's Brew in Pakistan," World Policy Journal, XXIV: 1 (Spring 2007) pp. 89-96.

[8] Robert Hathaway, "The Devil's Brew in Pakistan," World Policy Journal, XXIV: 1 (Spring 2007) p. 95.

[9] Saeed Ahmad Qureshi, "Two Views on Economic Performance," Dawn (June 9, 2003) http://www.dawn.com/2003/06/09/ebr1.htm

[10] For a complete explanation of the importance of reforms and institutional development for the Failed Take off School see Jennifer Bremer and John Kasarda, "The Origins of Terror: Implications for U.S. Foreign Policy, The Milken Institute Review, Fourth Quarter 2002.

[11] William Easterly, The Political Economy of Growth Without Development: A Case Study of Pakistan (Washington: World Bank Development Research Group, June 2001).

[12] Shahid Husain, "Pakistan's Future and U.S. Policy Options," in Working Group Meeting on Economic Revival (Washington: CSIS, November 27, 2001).

[13] Aqdas Ali Kazmi, "Production, Distribution or Diversion," Dawn (July 28, 2003) http://www.dawn.com/2003/07/28/ebr2.htm

[14] Ishrat Husain, "Pakistan's Economic Turnaround - An Untold Story," in Pakistan Supplement Global Agenda, World Economic Forum Annual Meeting 2005, Davos, January 2005, p. 1.

[15] See for example Ashfaque H. Khan, "The Economy at Take-Off Stage," Dawn (May 5, 2003) http://www.dawn.com/2003/05/05/ ebr3.htm

[16] Naween A. Mangi, "And the World's Top Maket is...Pakistan," Business Week (April 11, 2003) http://www.businessweek.com/ bwdaily/dnflash/apr2003/nf20030410_4232_db039.htm

[17] Saeed Ahmad Qureshi, op. cit

[18] Ashfaque H. Khan, op. cit.

[19] Figures are from Ministry of Finance, Government of Pakistan "Presentation on Pakistan on the Road of Sustained Economic Recovery", May 6, 2007

[20] Oxford Analytica, "Pakistan: Energy Crisis is Looming," January 22, 2007.

[21] Government of Pakistan, Pakistan in the $21^{\text {st }}$ Century: Vision 2030 (Islamabad: Planning Commission, August, 2007).

[22] Government of Pakistan in the 21st Century: Vision 2030 (Islamabad: Planning Commission, August 2007) p. XV.
[23] Shahid Javed Burki. "Causes of the Crisis," Dawn, February 12, 2008. http://www.dawn.com/2008/02/12/op.htm\#1

[24] M. Sharif, "Sustaining High Economic Growth in a Rapidly Changing Domestic, Regional and Global Economic Environment, The News, International, Business and Finance Review, March 10, 2008 .

[25] Shahid Javed Burki, “Aspects of Economic Take-off,” Dawn, June $14,2005$.

[26] Shahid Javed Burki, “An Expansionary Budget,” Dawn, June 21, 2005.

[27] Jennifer Bremer and John Kasarda," The Origins of Terror: Implications for U.S. Foreign Policy," Milken Institute Review, Fourth Quarter 2002, pp. 34-48

[28] 2008 Index of Economic Freedom (Washington: Heritage Foundation, 2008) p. 306

[29] James R. Barth,Tong Le, Wenling Lu, Triphon Phumiwasana, and Glenn Yago, Capital Access Index, 2007 (Santa Monica: Milken Institute, 2008) p. 1.

[30] Shahid Javed Burki, "Causes of the Crisis," Dawn, February 12, 2008. http://www.dawn.com/2008/02/12/op.htm\#1

[31] Zia-ul-Haq Sarhadi, "Need for a Viable Energy Policy," The News, Business and Finance Review, November 19, 2007.

[32] Robert Looney, "Energy and the Pakistani Economy: An Exploratory Analysis to 2035," in Robert Hathaway ed., Fueling the Future: Meeting Pakistan's Energy Needs in the $21^{\text {st }}$ Century (Washington: Wilson Center, March 2007) pp. 93-104

[33] Pakistan Infrastructure Implementation Capacity Assessment (PIICA) (Washington: World Bank, November 22, 2007) p. viii.

[34] Oxford Analytica, "Pakistan: Much-Needed Tax Reform is Unlikely This Year," April 19, 2007.

[35] Shahid Javed Burki, "The Economy Under Pervez Musharraf," Dawn, October 17, 2007.

[36] Ayesha Siddiqa, Military Inc.: Inside Pakistan's Military Economy (London: Pluto Press, 2007) p. 242.

[37] Shahid Javed Burki, "The Economy Under Pervez Musharraf," Dawn, October 17, 2007.

[38] Shahid Javed Burki, "The Economy Under Pervez Musharraf," Dawn, October 17, 2007

[39] Robert Looney and Robert McNab, "Pakistan's Economic and Security Dilemma: Expanded Defense Expenditures and the Relative Governance Syndrome," Contemporary South Asia 16:1 (March 2008) pp. 63-82.

[40] Robert Looney and Robert McNab, "Pakistan's Economic and Security Dilemma: Expanded Defenses Expenditures and the Relative Governance Syndrome, Contemporary South Asia, 16:1 (March 2008) p. 81

[41] Shahid Javed Burki, “Arithmetic of Discontent," Dawn, December 11,2007

[42] Shahid Javed Burki, "Reaching the Disadvantaged," Dawn, December 18, 2007.

[43] Shahid Javed Burki, "Reaching the Disadvantaged," Dawn, December 18, 2007.

[44] Hilton Root, "The Political Economy of State Failure," The Milken Institute Review, Second Quarter 2005, p. 68.

[45] Shahid Javed Burki, "Analysing Political Violence," Dawn, September 18, 2007

[46] Shahid Javed Burki, "Inequality and Development," Dawn, June 26, 2007.

(c) Robert Looney; Licensee Bentham Open.

This is an open access article distributed under the terms of the Creative Commons Attribution License (http://creativecommons.org/licenses/by/2.5/), which permits unrestrictive use, distribution, and reproduction in any medium, provided the original work is properly cited. 